\title{
Climate Change and the Struggle for Natural Resources in Africa
}

\author{
Nwankwo, Donna-Carine Nkeiruka ${ }^{1}$; Ogali, Matthew Dayi
}

${ }^{1} \mathrm{PhD}$ - Research Student, Department of Political and Administrative Studies, University of Port Harcourt, Nigeria.

${ }^{2} \mathrm{PhD}$, Lecturer, Department of Political and Administrative Studies, University of Port Harcourt, Port Harcourt, Nigeria.

\begin{abstract}
The study examined the negative impact of climate change in Africa that has negatively impacted livelihoods across the continent. The region that was formerly a robust agrarian belt, animated with a culture based on agro-social energy, is fast becoming a shadow of its erstwhile glorious image. It generally explains how climate change and its implications for natural resource use are fast changing the developmental and migratory narrative, as well as conflict, in Africa. The 'Word System Theory' was adopted as the theoretical framework to explain the impact of climate change in Africa. Primary and secondary sources were used to generate data for the study. The central thesis is that the colossal environmental degradation in various parts of Africa, including the Lake Chad Basin, has resulted in a struggle over the available, but fast shrinking, natural resources in the region. The numerous crises that have arisen from the struggle to make a better livelihood in the African region also has a contingent effect on other continents of the world, particularly in terms of migratory movements. The inevitable conclusion is that without relevant, creative, functional and sustainable education on greening the environment and effective pollution control the current crises in the region would not abate. It therefore recommended that stringent measures be taken against countries that emit greenhouse gases, and that urgent strategies be introduced to generate employment for sustainable livelihoods as means of curtailing crises in the region.
\end{abstract}

Keywords-Climate Change, Natural Resources, Environment, livelihood, Migration.

\section{INTRODUCTION}

The world generally is bedevilled with the negative impact of climate change. The African continent is not an exception as the ecological system can long be what it used to be since the global war on climate change. Climate change could be seen as an increase in global temperature for an extended period. The reported of Intergovernmental Panel on Climate Change in 2014 revealed that countries contribute differently to greenhouse gases associated with the cause of climate change. However, their levels of vulnerabilities vary. The continuous increase in the atmospheric temperature has resulted in a series of disasters globally. The developed countries, due to their advanced technology, emit greenhouse gases while in Africa, lack of those facilities made it difficult to manage climate crisis. The worst continents in the emission of carbon dioxide are Asia and the Pacific as a result of their new advances in industrialisation. The level of air pollution in the developing countries is outrageous, especially in China which contributes immensely to the environmental crisis ongoing in the developing world. Air pollution does not only affect the quality of the environment and economic development as an environmental issue. However, climate change increases related challenges of global warming to the environment and economic growth in parts of the world, mostly on regions that found it difficult to adapt to the situation (Kelsey, 2017).African countries are vulnerable to the impact of climate change due to their weak economic base and technology, as well as their inability to adapt and mitigate the problems associated with climate change.

Moreover, Petersen and Stephenson in 1991 stated that the exploitation of water resources in developing countries is linked with economic development. Also, the formulation of various agricultural projects by governments in the African region,such as irrigation and rural water supply are geared towards benefits from the environment.The Food and Agriculture Organisation of the United Nations (FAO), in 2014, revealed thatin Africa, 46.8 per cent of the arable land area is utilised for agriculture permanently for pasture and crop production. The rising temperature in the region and the desertification it has caused in previously forest areas and agricultural land have grave implications for sustainable livelihood of the people. Unavailability of water for agriculture made some African countries, such as Sudan and Somalia, to withdraw a sizeable volume of water for agricultural activities through the construction of dams. 
Moreover, FAO (2016) reported that climate change undermines the livelihood of the populations that depend on agriculture for survival.

\section{THEORETICAL FRAMEWORK}

The 'World-System Theory' was adopted as the theoretical framework for this paper. Immanuel Wallerstein propounded the theory in the 1970s. The proponents argued that the position of the state could be viewed broadly within a legal, economic and political framework of relations involving other states at various levels of development. This is what he referred to as the 'world system.' The theory explains that the interaction between countries of the world has an input and output outcome in the political systems of the countries involved. Wallerstein rejected the concepts of the sovereign state and national society as constituting a social system. To him the only social system is the world system (Roxborough, 1981, p. 51). This world system, to him, is essentially a capitalist system, which forms a network in which productive activities in one part of the system have implications for the other. In other words, the world system divides states into core of capitalistically developed and another set of underdeveloped peripheral societies.

Following this theory, global warming is an ecological challenge that variously affects the diverse nations of the world. They could be categorised into those that generate greenhouse gases and those that are mostly affected by the impact of global warming. Climate change is responsible for most of the natural disasters in the world and causes social and regional inequalities and dislocations globally. Furthermore, the theory elucidates exactly how geopolitical arrangements in the global economy ensure that the implications of burning fossil fuels are not evenly shared throughout the world.

It distinguishes between the different ranks of the countries of the world in terms of their responses to globalisation. The theory could be adapted to explain the massive emission of greenhouse gases into the environment by the developed countries, also known as the core countries. These hazardous gases are emitted as the developed countries process goods and services for their consumption and commercial purposes, but which affect the third world countries, also known as the peripheral countries that contribute less of the greenhouse gases that impact the environment. The African continent belongs to the peripheral countries in which a large number of their populations mostly depend on agricultural activities and extraction of natural resources for livelihood.Wray and Dantas revealed that low productivity, the participation of inactive people in the work-force and stagnate wages of workers are associated with problems of demand. The situation is common in Africa, where climate change has reduced the resources and employment opportunity of the populace.

A dysfunctional relationship exists between the core countries, i.e. the developed countries, presumed to be responsible for colossal greenhouse gas emissions into the environment and therefore significant contributors to climate change, and the peripheral countries that are impacted by the concomitant effects. In between the core and the peripheral countries are the intermediate countries known as the semi-peripheral category of the world economy, which are more advanced and economically more diverse than the peripheral countries. As a result of some level of advancement of the semi-peripheral and mostly the advanced core countries of the world, due to their high technological know-how, services and information, raw materials are transferred from other categories to the core countries for processing into finished goods. However, the processed goods are finally shipped back to the peripheral countries and sold at a higher rate. The situation in the peripheral countries is worsened since they do not have the technology, economic power, and adaptive measures to curtail the impact of climate change. The separation of countries of the world and their level of manufacturing of goods for other countries, is a creation of economic and political global inequality that have direct effects on global climate change. Below is a model that can be used to explain how raw materials are produced in peripheral and semi-peripheral countries but finally processed in the core countries of the world.

Movement of raw materials from periphery and semiperiphery countries $\rightarrow$ the core $\rightarrow$ raw materials processed $\rightarrow$ emission of GHG $\rightarrow$ moving of finished goods $\rightarrow$ periphery and semi-periphery countries.

\section{RESEARCH DESIGN AND METHOD}

The study adopted the descriptive and historical method of data analysis in explaining the struggle in Africa as a result of the impact of global climate change. Opinions of some scholars on the Lake Chad Basin, a region in Africa and one of the regions of global reference to climate change were captured. The secondary sources are from documentaries of Food and Agriculture Organisation of the United Nations Regional Office in Africa, library and internet.

\section{RESULTS AND DISCUSSION}

The result of the study revealed the colossal impact of climate change on the natural resources in Africa. The impact of climate change led to the shrinking of Lake Chad and its tributaries. Also, it resulted in a severe 
drought in the Horn of Africa. However, the study exposed the core countries as a significant contributor to greenhouse gases that cause of climate. The core is made up of the developed countries of the world with advanced technology and sustainable economic power to adapt and mitigate the impact of climate change in their region. European countries are developed nations. They involved mainly in the donation of funds, assisting with aid, trade and policy on investment, as well as facilities to the developing countries through the United Nations Development Programme. They support all forms of bilateral and multilateral assistance to the developing countries, which affect industrial and agricultural development in the region.On the other hand, those countries referred to as the periphery are the developing nations that are partly on the African continent. The core countries contribute more to the causes of climate change, but the peripheral suffer more from the impact of climate change. Africa is known to be afflicted with high rate of poverty, hunger and low technology. The population depends mainly on agriculture as the means of livelihood. Massive populations in Africa are struggling to survive amid available but poorly managed resources in the region. The resultant effects of this situation in Africa are poverty, hunger, unemployment, migration, drug and human trafficking, proliferation of arms, terrorism, among others.

The drying of the ground known as El Niño and the La Niña, the cold phase of the climatic situation, have wreaked severe havoc on agriculture in Africa. African countries are the most affected with natural disasters such as storms, flooding and drought-related climate change. These disasters have resulted in food insecurity, leading to the death of many, and displaced massive populations, thus creating conflicts in the region. In the face of climate change the survival effort of the affected people is tough and therefore hardly able to attain food security. An example is the severe drought that led to a food crisis in the Horn of Africa in 2011, affecting twelve million people. Countries that suffered from this impact of climate change associated with famine were Ethiopia, Somalia, Djibouti, Uganda and Kenya. Underlining issues created in Africa by climate change include scarce resources, migration, poor governance, unsustainable livelihoods, conflict, and proliferation of arms, among others, and the situation has worsened in terms of mitigating and adapting to climate disasters.Di Marco in 1972 captured poor educational background and training processes as some factors responsible for economic setbacks of most countries in the African continent. The implication of these factors of economic devastation is connected to migration, population growth and unemployment in the region among others in the aspect of the regional development of Africa.

The devastation of the natural environment is on the rise. World's population has been on the increase despite natural disasters that occur in diverse ways with implications for natural resources. In 2011, the percentage of urban population was 52.6 per cent against the rural population of 47.5 per cent (Food and Agriculture Organisation of the United Nations, 2014). However, the Food and Agriculture Organisation of United Nations in 2014 captured that in their data analysis at the regional levels Africa has the most significant rural populace in the world. That is to show how committed the people are in agriculture. Therefore, water and land resources are under severe pressure from the teeming population. The situation has gloomed the economic condition of those whose livelihood is dependent on those resources. The usual trade between African countries and other countries that rely on the supply of such resources drastically reduced because of the domestic issues in the region. The effect on the economy of some the African countries increased poverty level. The poverty gap for some African countries against national poverty from 2005 to 2012 was high. Hunger manifesting since the available resources can no longer sustain the majority of the people. During the International Conference on Lake Chad, African leaders, the SecretaryGeneral Food and Agriculture Organisation of United Nations, representatives from United Nations, and others governmental agencies lamented the severe degradation of the African region, mainly the Lake Chad, by climate change (Lake Chad Basin Commission, 2018).

The African region has been battling with a high rate of poverty and illiteracy. The impact of climate change on the means of livelihood of a larger population has rendered many jobless. The larger affected population in the rural areas are left to the mercy of the degraded environment that supports their well-being. Also, the Food and Agriculture of the United Nations Regional Office for Africa in 2014, recorded a broad decline in agricultural population in all the sub-regions from 1990 to 2012. Many of the victims of climate change struggle to earn a living from the available natural resources in the region; some change their trade, while others changed locations to cities to seek white-collar jobs. The destruction of natural resources by climate change in African countries also contributed to the massive migration of the population whose livelihoods rely mostly on agriculture to Europe and other parts of the world. Some of these migrants met their waterloo in the Mediterranean Sea, others in the Sahara Desert, among others since the struggle over available resources in Africa can no longer put food on their tables, 
thereby resulting in crises in different parts of the world, especially Africa that contributes less to greenhouse gases.

Climate change can be seen as a state of observable changes in the variability of the mean and changes in the mean properties. The changes can be confirmed through a statistical test in a particular area over a long time, for a decade or more. However, the United Nations Framework Convention on Climate Change stated that climate change is attributable indirectly or directly to human activities altering the natural climate variability and the atmospheric composition for an extended period.

Report from the Fourth Assessment of the Intergovernmental Panel on Climate Change in 2007 by the three working groups on Climate change impacts, i.e. physical science; adaptation and vulnerability; and mitigation of climate change greenhouse gas emission trends, discovered serious impacts of global climate change. The report established that human activities are responsible for climate change, and that if the causes of climate change are not checked, the phenomenon will cause more havoc to the global community.

Shrivastava (2007) also stated that a study carried out by scientists at the World Health Organization with the London School of Hygiene and Tropical Medicine, showed that 160,000 people die each year from the effects of global warming, ranging from malnutrition to malaria, in which children in developing nations are the most vulnerable. The number could almost be doubled by 2020 . It states that the effects of climate change on countries, sub-regions and regions vary in degree, magnitude as well as devastation levels. The level of mitigation and adaptation of such situations depend on the capabilities of states to manage based on their financial power and technology.

\section{CONCLUSION}

The study emphasised on climate change and its impact on natural resources in the African region. Agriculture is a primary means of livelihood for the population. Due to its naturally large agrarian area the continent is facing severe challenges from climate change. Africa is categorised among the peripheral countries as one of the poor regions of the world, battling with a high rate of poverty and hunger. It lacks financial power and technology to tackle most of the challenges in its domain, and is still suffering from the consequences arising from the exposure of the world to global disaster by the core countries. The impact of climate change in Africa destroyed the natural environment that most people rely on to make a living. A reference point is the entire Horn of Africa, and the shrinking of the Lake Chad as one of the global references to the impact of climate change. Also analysed is its severe effect on agricultural activities in the entire Lake Chad Basin, drought in Ethiopia, Somalia, Djibouti, Uganda and Kenya, among other countries in Africa. Waziri (2012) revealed the deterioration of the environment as it affects the socio-economic livelihood of the people. In line with the opinions of the previous scholars on the impact of climate change in Africa, Custodio and Gurguí in 1989 stated that water generally not merely groundwater might have a macroeconomic impact in countries, where water contributes a high proportion of the Domestic Product.These countries due to their massive agricultural production, source of income, foreign trade and employment of their population.However, some countries in Africa are also affected by flood and in other climateassociated disasters in the region. These effects resulted in scare resources in arable agricultural land, water resources, among others, as the population struggles over menial available resources for survival. The rate of water use has increased about three times higher than the rate of the global increase in population, which affects the availability of water and increases the demand. However, water prices may steadily increase to control demand of the commodity, which will likely affect farmers (Jain and Singh, 2003). The struggleculminated in various crises such as intra-migration and inter-migration, conflicts, arms proliferation, drug and human trafficking, terrorism and other crime-related trades to sustain livelihood by the displaced population in the region.

\section{Recommendations}

- Education is the most powerful weapon to change the population today and the next generation. African countries should see it as a prerequisite for curtailing the negative impact of climate change in the region so that the water and vegetation will be restored for a better livelihood for the people.

- Stringent measures should be imposed on consumers and businesses to reduce the greenhouse gases (GHG) that contribute immensely to climate change and the African Union should liaise with the United Nations to charge the industrialised countries to be paying for damages to the region.

- United Nations should call for climate alert on the degradation of African countries by climate change and apply faster strategies of greening the environment to promote employment for sustainable livelihood which will help in curtailing other crises existing in the region. 


\section{REFERENCES}

[1] Brooke, K. J. (2017). Environmental Economics in Developing Countries: An Introduction to the Special Issue. Journal of Environmental Economics and Management. November 2017, Volume 86: 1-7. Retrieved on 12/11/2019 from

https://www.sciencedirect.com/science/article/abs/pii/S009 5069617305879

[2] Custodio, E. \& Gurguí, A. (1989). Groundwater Economics. Elsevier, Amsterdam-Oxford-New YorkTokyo.

[3] Di Marco, L. E. (1972). International Economics and Development: Essays in Honor of Raúl Prebisch. Elsevier, Amsterdam-Oxford-New York-Tokyo.

[4] Food and Agriculture Organisation of United Nations (2014). Statistical Year Book: Africa Food and Agriculture. Accra: FAO Regional Office for Africa, www.fao.org/africa.

[5] Food and Agriculture Organization of the United Nations (2016). The State of Food and Agriculture: Climate Change, Agriculture and Food Security. Rome: Food and Agriculture Organization of the United Nations.

[6] Intergovernmental Panel on Climate Change (2007). Climate Change: Impacts, Adaptation and Vulnerability. Cambridge: Cambridge University Press.

[7] Intergovernmental Panel on Climate Change (2014). Global and Sectoral Aspects, Working Group 11, Contribution to the Fifth Assessment Report of Intergovernmental Panel on Climate Change. Impact, Adaptation and Vulnerability: Part A. Cambridge: Cambridge University Press.

[8] Jack, B. K. (2017). Environmental Economics in Developing Countries: An Introduction to the Special Issue. Journal of Environmental Economics and Management. November 2017, Volume 86: 1-7. Retrieved on 12/11/2019 from

https://www.sciencedirect.com/science/article/abs/pii/S009 5069617305879

[9] Jain, S. K. \& Singh V. P. (2003). Water resources System Planning and management. Elsevier Amsterdam, The Netherlands.

[10] Petersen, M. S.\& Stephenson, D. J. (1991). Water Resources Development in Developing Countries. Elsevier, Amsterdam-Oxford-New York-Tokyo.

[11] Sanusi, I. A. (2018). International Conference on Lake Chad. Newsletter Conference Edition, February 27. Abuja: Lake Chad Basin Commission.

[12] Shrivastava, A. K. (2007). Global Warming. New Delhi: A P H Publishing corporation.

[13] Tregear, P. \& Burley, J. (1970). African Development and Europe: Report of a Seminar of the International Student Movement for the United Nations.

[14] United Nations Framework Convention on Climate Change (2011). Fact Sheet: Climate Change Science - the Status of Climate Change Science Today.

[15] Wallerstein, I. (1981). Theories of Underdevelopment. London: Macmillan Press Ltd.
[16] Waziri, I. M. (2012) The Lake Chad Basin as a Historical S ocio-economic Platform of Relationship and Livelihood for the People in the Region, in Gworgwor, N. A. ed. The Socio-Economic Sustainability of Livelihood in the Lake Chad Basin. Proceedings of the Alexander von Humboldt Kolleg International Conference, University of Maiduguri, December.

[17] Wray, R. \& Dantas, F. (2019). Handbook of Economic Stagnation. Retrieved on 11/11/219 from https://www.elsevier.com/books/handhook-of-economicstagnation/wray/978-0-12-815898-2. 